\title{
The Problems and Consequences of the Biodiversity Conserva- tion: A Case Study from Bangladesh, India, Nepal, and Pakistan
}

\author{
Medani P. Bhandari
}

$\mathrm{PhD}$, Professor and Deputy Program Director of Sustainability Studies, Akamai University, Hawaii, USA, International Program Director, Atlantic State Legal Foundation, NY, USA, Executive Director, Human Survival Foundation, Glasgow, UK

\begin{abstract}
Biodiversity, a measure of the health of biological system, is a variation in the life form in a given ecosystem over a time period. Biodiversity supports the earth's life systems by stabilizing the foundation for crucial ecosystem services. Reviewing literature, this paper explains the current status of biodiversity in Bangladesh, India, Nepal, and Pakistan. The author chose these South Asian countries because despite housing spectacular natural beauty and biological wealth and significantly contributing to the life support systems, biodiversity has been severely threatened by direct and/or indirect actions of human beings in this world's second most densely populated region. Many natural habitats have been fragmented from excessive human pressures. Some species are in the verge of extinction. As further threats to biodiversity continue, it is likely that these countries might experience unprecedented environmental consequences, such as floods and climate change. In response to these possible unprecedented changes, attempts have been made to conserve and improve the ecosystem services through the conservation of biodiversity; however, all these activities have been insufficient to replenish the lost resources that have been overexploited. The author argues that there is an urgent need of institutional setup to disseminate a highly reliable and meaningful information system at different levels, which is missing in these countries.
\end{abstract}

Keywords: South Asia, transboundary, institution, biodiversity, forest, hotspots, conservation.

JEL Classification: Q23, Q5.

(C) The Author, 2018. This article is published with open access at Sumy State University.

\section{Introduction}

A rapidly increased global population has impacted the biodiversity in large scale. The South Asian region, the world's second largest population concentration, has been experiencing population pressure on its ecosystems that support rich biodiversity. Agricultural lands have been expanded onto forest, more roads are built, and urban areas are organically sprawling. Research has shown that ecosystems containing different plant species in certain location are more productive than those containing only one of those species (Fargione et al., 2008). The arguments are that maintaining high biodiversity may help meeting the needs for the growing population while restoring ecosystem services. However, humans' direct and indirect actions have been irreversibly changing the biodiversity in this region (MEA, 2005). Direct influences immediately impacting biodiversity include, but not limited to, the construction of dams and roads, clearing of forests for farming and urban expansion. Indirect drivers are a bit more difficult to comprehend. For example, it takes a long-term research to understand how a growing population or cultural belief could detrimentally influence the rate at which ecosystem processes unravel. Though Malthusian logic states that larger populations require more land to support the growing population, neoliberal views state that wealthier populations consume more resources, but advances to certain technological innovation, and utilizes least amount of resources with much less damage. Judeo Christianity on the other hand believes on the effective uses of available resources for the welfare of human kinds. Though neoclassical ideologues argue in favor of brilliant innovation of new tools to try to conquer the forces of nature, the recent flood and climate changes suggest that nature is more powerful than physical forces human can apply. Radical weather patterns caused by global warming disrupt the land production system to a much larger scale than the uses of fertilizer to increase agricultural production in smaller units. Green revolution no doubt, has saved billion of lives from starvation, the contributions of fertilizers, insecticides, and pesticides have far less significant than the widespread of famine caused by the climate changes associated with the rapid losses of biodiversity; for example, the case of Ethiopian famine due to the loss of biodiversity, and recent flooding and landslides occurring in the South Asian countries. These simple examples justify the importance of biodiversity conservation for sustaining our world ecosystems. 
Environmental stress, environmental disturbances, extreme environmental conditions, severe limitation of resources, introduction of non-native species, and geographic isolation of various species have been the major contributors to the losses of biodiversity and climate changes. These factors have accelerated the losses of habitat through the overexploitation of valuable flora and fauna. Though neoclassical economists argue that technological change allows a more efficient use of resources, it has been observed that a cultural belief can impart much cheaper conservation ethic with sustainable approach than technological means. These cultural beliefs have been in actions both in wealthy and poorer communities since time immemorial to conserve both small species such as insects that depend on one or two trees, and bigger species such as elephant, tigers, lynx or jaguars that require large swath of forested biomes and their surrounding ecosystems.

People motivated by the philosophy of Judeo Christianity believe that resources are for the uses of human kinds. These motives have brought more rapid negative changes in biodiversity during the past 50 years than at any time in human history. Projected scenarios indicate that these rates will continue unabated (MEA, 2005: 1-2) unless serious control measures are devised. For more than 50 years, scientists have debated the hypothesis that biodiversity stabilizes ecosystems (Fargione et al., 2008). The arguments are that disappearance of species or even a single species has ripple effects from one ecosystem to another, and a loss of species impacts the ecosystem in unexpected ways. An extinction of certain species primarily disrupts the food chain, and exposes the ecosystem to a greater risk. Though natural disasters such as the Asian tsunami of 2004 triggered a series of devastating losses killing over 230,000 people in fourteen countries and many flora and fauna, thousand of species were lost due to human actions. When natural disaster and human made destructions are compared, natural disasters are more rapid than humans' actions, but human actions have been irreversible and a combination of both humans' actions and natural disasters have exacerbated the biodiversity losses at a much faster rate. For example, an introduced of non-native species, and overexploitation of species followed by draught detrimentally affect ecosystem processes. Besides, nutrient loading in water bodies, selective agricultural breeding, and climate change also impact biodiversity, and these activities have triggered natural processes in a destructive manner. Thus, research has concluded that human actions are inducing powerful natural processes, such as flood, and a change in plant production system due to climate changes that impact on biodiversity.

Though human beings have been benefited over the last century from the conversion of natural ecosystems to cultural landscape and by exploiting the biodiversity, a large body of literature also reveals that biodiversity contributes directly (through provisioning, regulating, and cultural ecosystem services) and indirectly (through supporting ecosystem services) to many constituents of human well-being, including food security, basic material for a good life, health, good social relations, and freedom of choice and action (MEA, 2005: Finding 2, p. 5).

Changes in biodiversity impact the living conditions of people largely depending upon primary economic activities, and indirectly affect all living beings through unprecedented climate changes. A large number of people depending upon primary activities in South Asia, for examples, $73 \%$ of the total population of Bangladesh, 71\% population of India, 83\% of Nepal, and 64\% of Pakistan (World Bank, 2011) are severely impacted as the ecosystem services change. Poverty is rampant in these countries, where the majority of the population lives in a dollar a day. As of 2008 estimation in Bangladesh, $41.3 \%$ of the total population lives below \$1-a-day, 33.5\% in India, 24.1\% in Nepal and 17\% in Pakistan (Desai et al., 2011). These countries though have varied altitudes, climates, geomorphic and rainfall patterns, many spatial extents share similar ecosystem services; for example, the Thar Desert and arid areas in north-west India and southern Pakistan have similar ecosystem services. Likewise, high altitude cold deserts in the upper Himalayas and Deosai plains in Kashmir, and two rich biodiversity hotspots in the eastern Himalayas (Nepal, north-eastern India), and Sunderbans transboudaring between Bangladesh and India all are interrelated to each other (Figure 1) (SAARC, 2010: World Bank, 2011). Thus, an impact on biodiversity in one location would have ripple effects in the proximate areas that requires institutional setups to disseminate right information in a coordinate manner across nations.

Probably, because of the geomorphic commonalities and economic interrelationships in the ecosystem services, all these countries of South Asian region, started their biodiversity conservation activities only after the United Nations Conference on the Human Environment held in Stockholm in 1972. This conference paid much attention to the conservation and management of various forest resources to enhance high biodiversity. 
The National Biodiversity Strategy and Action Plan (NBSAP) of Bangladesh enacted in 2004 is an example of government's full commitments to various international agreements including the Convention of Biodiversity (Government of Bangladesh, 2005: v). In 1972, the Wild Life Protection Act was passed in India with a provision of a Wild Life Advisory Board (WLAB) enshrined in the country's constitution. The WLAB directs the government offices to regulate the hunting of wild animals and birds, creates provisions to declare certain areas as sanctuaries and national parks reserves. Additionally, the constitutional provision also guides the government to regulate trades associated with the animal products including the trading of live animals for the conservation and gene dissemination purposes (Vyas and Reddy, 1998). Similarly, Water (Protection and Control of Pollution) Act was passed in 1974, which opened the window for the establishment of Central and State Pollution Control Boards (CSPCB) for the prevention and control of water pollution. Additionally, the CSPCB authorizes the establishment of laboratories for analyzing water samples. Likewise, Air (Protection and Control of Pollution) Act was passed in 1981 (UN, 2002) to set air quality standards.

Similar to the cases of Bangladesh and India, Nepal also enacted several laws that have direct influences on the conservation of biodiversity; for example, National Forestry Plan of 1976; National Conservation Strategy of 1988; Master Plan for the Forestry Sector of 1989; Nepal Environmental Policy and Action Plan of 1993; National Biodiversity Action Plan of 2000 and Nepal Biodiversity Strategy of 2002 (ADB, 2006) all have significantly contributed to the conservation of biodiversity. Similarly, though the government of Pakistan issued the National Forest Policy in 1955, The National Forest Policy in 1962, The Forest (West Pakistan Amendment) Act in 1964, major conservation activities started after 1972. The Punjab Wildlife (Protection Preservation Conservation and Management) Act and Rules were enacted in 1974, the Balochistan Wildlife Protection Act in 1974 and Rules in 1975, the National Wildlife and Forest Act were enacted 1975 and Rules in 1976. Likewise, Pakistan government prepared the Forestry Sector Master Plan in 1992; Environmental Protection Act in 1997; Biodiversity Action Plan in 2000; and Natural Forest Policy in 2001. All these activities much focused on the conservation of the biodiversity (Government of Pakistan, 2009). Other efforts made by the South Asian countries after the Rio Summit in 1992 are presented in Table 1.

Table 1. Institutional arrangements for biodiversity conservation

\begin{tabular}{|c|c|}
\hline $\begin{array}{l}\text { Bangladesh } \\
1994 \text { CBD ratification } \\
1995 \text { Environment Conservation Act (ECA) } \\
1997 \text { Environmental Conservation Rules (ECR) } \\
2004 \text { National Biodiversity Strategy Action Plan (NBSAP) }\end{array}$ & $\begin{array}{l}\text { India } \\
1993 \text { India becomes signatory to CBD } \\
1999 \text { National Policy and Macro-level Action Strategy on } \\
\text { Biodiversity issued. NBSAP process initiated within MoEF } \\
2000 \text { National Biodiversity Strategy Action Plan (NBSAP) } \\
\text { process begins Biodiversity Bill placed before Parliament, } \\
\text { Parliamentary committee accepting depositions }\end{array}$ \\
\hline $\begin{array}{l}\text { Nepal } \\
1992 \text { Signed the Convention on Biological Diversity } \\
1996 \text { Biodiversity Action Plan begins } \\
1996 \text { Environment Protection Act enacted } \\
1997 \text { Endorsement of the Environment Protection Regulations } \\
1998 \text { Endorsement of the Ninth Plan (1998-2002) } \\
\text { 2000 Completion of the National Biodiversity Action Plan } \\
\text { preparation }\end{array}$ & $\begin{array}{l}\text { Pakistan } \\
1992 \text { National Conservation Strategy } \\
1994 \text { Convention on Biological Diversity (CBD) } \\
1997 \text { Pakistan Environment Protection Act } \\
1999 \text { Biodiversity Action Plan (BAP) } \\
\text { 2000 Biodiversity Action Plan } \\
2005 \text { Pakistan Environmental Policy } \\
2005 \text { Plant Breeders' Rights Act (draft), the Biosafety Rules }\end{array}$ \\
\hline
\end{tabular}

Source: Carew-Reid, 2002; Desai et al., 2011.

With the above background information, we first present the geographic extents of biodiversity distribution, biodiversity hotspot areas, problems faced to conserve biodiversity, institutional approaches to biodiversity conservation, and sustainable aspects of biodiversity conservation in these countries. This will be followed by a conclusive summary.

\section{Biodiversity distribution in the region}

These four countries (Figure 1) cover 4,374,537 sq. km. surface area (CIA, 2010). As of 2001, in average about $16 \%$ of land surface is under the dense forest canopy. These forest covers are rich in biodiversity; however, these forests are degrading or depleting rapidly (Table 2). 
Table 2. Forest area and area change

\begin{tabular}{|l|c|c|c|c|c|c|c|}
\hline \multicolumn{4}{|c|}{ Extent of forest (2010) } & \multicolumn{5}{c|}{ Annual change rate } \\
\hline Country & $\begin{array}{c}\text { Forest Area } \\
(1000 \text { ha) }\end{array}$ & $\begin{array}{c}\% \text { of land } \\
\text { area }\end{array}$ & $\begin{array}{c}\text { Area per 1000 } \\
\text { people (ha) }\end{array}$ & $\begin{array}{c}1990-2000 \\
(1000 \text { ha })\end{array}$ & $\begin{array}{c}1990-2000 \\
(\%)\end{array}$ & $\begin{array}{c}2000-2010 \\
(1000 \text { ha })\end{array}$ & $\begin{array}{c}2000-2010 \\
(\%)\end{array}$ \\
\hline Bangladesh & 1442 & 11 & 9 & 3 & -0.2 & -3 & -0.2 \\
\hline India & 68434 & 23 & 58 & 145 & 0.2 & 304 & 0.5 \\
\hline Nepal & 3636 & 25 & 126 & 92 & -2.1 & -26 & -0.7 \\
\hline Pakistan & 1687 & 2 & 10 & 41 & -1.8 & -43 & -2.2 \\
\hline South Asia & 80309 & 19 & 51 & 7 & 0 & 221 & 0.3 \\
\hline World & 4033060 & 31 & 597 & 8323 & -0.2 & -5211 & -0.1 \\
\hline
\end{tabular}

Source: FAO, 2011: 112.

Despite much pressure on the existing natural resources, South Asia still holds approximately $14 \%$ of the world's remaining mangrove habitations. Bangladesh alone houses 82 threatened wetlands. Likewise, the Himalayas have been important niche for many flora and fauna. The Hindu Kush Himalayan belt homes about 25000 major plant species, comprising 10\% of the world's flora and fauna. Table 3 presents the number of floral and faunal in the study area.

Table 3. Comparative overview of biodiversity distribution in the region

\begin{tabular}{|l|c|c|c|c|c|c|c|}
\hline \multicolumn{1}{|c|}{ Country } & $\begin{array}{c}\text { Geographical } \\
\text { Area (sq. km) }\end{array}$ & $\begin{array}{c}\text { Number of } \\
\text { flowering } \\
\text { plants \& ferns }\end{array}$ & Birds & Mammals & Reptiles & Amphibians & Fish \\
\hline Bangladesh & 143,998 & 7,400 & 632 & 125 & 154 & 23 & 736 \\
\hline India & $3,287,263$ & 17,000 & 1,200 & 350 & 453 & 272 & 748 \\
\hline Nepal & 147,181 & 5,568 & 844 & 181 & 100 & 43 & 185 \\
\hline Pakistan & 796,095 & 6,000 & 666 & 188 & 174 & 16 & 156 \\
\hline South Asia & & 3400 & 1044 & 900 & 351 & 1900 \\
\hline World & 4,629 & 9,672 & 6,900 & 4,522 & 25,000 \\
\hline
\end{tabular}

Source: compiled from Vié et al., 2008; IUCN, 2007: 16; IUCN, 2010.

Of the 10,000 endangered bird species available in the world, 163 endangered bird species are found in South Asia (Table 4) (Birding.com, 2010).

Table 4. Number of endangered, vulnerable, and rare species of the study areas

\begin{tabular}{|l|c|c|c|c|c|c|c|c|c|c|c|c|}
\hline & \multirow{2}{*}{ Total } & \multirow{2}{*}{$\begin{array}{c}\text { Mammal } \\
\mathrm{s}\end{array}$} & Birds & Reptiles & \multirow{2}{*}{ Amphibians } & Fishes & \multirow{2}{*}{ Molluscs } & \multirow{2}{*}{$\begin{array}{c}\text { Other } \\
\text { inverts }\end{array}$} & \multirow{2}{*}{ Plants } & \multicolumn{3}{|c|}{ Plants (classification) } \\
\hline India & 659 & 96 & 79 & 25 & 66 & 40 & 2 & 109 & 246 & 152 & 102 & 251 \\
\hline Bangladesh & 109 & 34 & 28 & 20 & 1 & 12 & & 2 & 12 & 0 & 21 & 1 \\
\hline Nepal & 81 & 32 & 32 & 7 & 3 & & & & 7 & 2 & 5 & 10 \\
\hline Pakistan & 99 & 23 & 27 & 10 & & 22 & & 15 & 2 & 2 & 2 & 5 \\
\hline & 948 & 185 & 163 & 62 & 69 & 74 & 2 & 126 & 267 & 156 & 103 & 267 \\
\hline
\end{tabular}

Sources: ESCAP 2010:191 (Endangered, vulnerable, rare).

According to Table 4, almost $20 \%$ amphibians are under the threatened categories followed by $15.61 \%$ birds, 6.89\% reptiles, 5.4\% mammals, and 3.89\% fish species among the total animals found in these four countries. Bangladesh, Nepal, and Pakistan have been facing problem of political unrest, growing population pressures, extreme poverty and food insecurity since for a long time. These problems are directly impacting various ecosystem services. Despite India having strong economy, bureaucratic, and political stability, a large number of people living close to biodiversity hotspot areas still depend on the primary activities for their survival. Many biodiversity rich areas have transboundary extensions. Conservation initiatives in these countries require the involvement of stakeholders of neighboring countries. In the lack of strong institutional setup to monitor and conserve the status of biodiversity, many of the biodiversity rich areas have also turned into hotspots. 


\section{Transboundary biodiversity}

Located along the world largest deltaic regions with $80 \%$ flood plains formed by the Ganges and Brahmaputra rivers (Figure 1) and their tributaries, Bangladesh has the most rapidly changing ecosystems, but this country houses over 5,000 aquatic flora and fauna (WRI, 2010). Along the Brahmaputra's delta are the Sunderbans that extend between Bangladesh and India. These Sunderbans are among the world's most significant mangrove forests and serve as good habitats for the Royal Bengal Tiger (UNEP-DA, 2008: 30). Over 700 rivers entering Bangladesh (Figure 2a) make braided channels covering about 24,000 km of vast network of wetlands. These rivers form Beels (perennial water body), baors (ox-bow lake), and haors (saucer shaped depressed land which remains underwater for more than 6 months), and these ecological niches provide a huge refuge for amphibian and aquatic lives (ADB, 2004: 2; Rashid, 1991: 15). Very little land area is above $10 \mathrm{~m}$ sea level (ADB, 2004). Bangladesh has only $12 \%$ hilly areas and about $8 \%$ terrace farms. Wetlands contribute more significantly in the conservation of biodiversity in Bangladesh.

India is located in the tri-junction of three realms - Afro-tropical, Indo-Malayan and Paleo-Arctic realms. The geography of India is divided into 10 biogeographic regions, and it ranks $12^{\text {th }}$ among the mega biodiversity countries of the world (Government of India, 2010). India, known for its rich heritage of biological diversity, has so far documented over 91,200 species of animals and 45,500 species of plants in its ten biogeographic regions. Besides, it is recognized as one of the eight Vavilovian centers of origin and diversity of crop plants, having more than 300 wild ancestors and close relatives of cultivated plants, which are still evolving under natural conditions (Government of India, 2009: 1). India has the third largest amphibian population in Asia. The amphibian fauna of India comprises of 272 species of which 167 (66.3\%) are endemic to the country. These biodiversity spots include forests, grasslands, wetlands, coastal and marine and desert ecosystems.

Nepal is located along the boundaries of the Eurasian, Indian, and Tibetan tectonic plates. Undulated terrain, complex geology, and maximum change in elevation (32 m to $8848 \mathrm{~m}$ in 1.3 degree of latitude) with minimum horizontal distance makes it richest in various biodiversity in the region. Due to unique geographical location and a wide range of climatic conditions, Nepal offers a typical example where $34,186.62 \mathrm{sq} . \mathrm{km}$ $(23.23 \%)$ of the total geographic area of the country has been set aside under military protection for the conservation of rare and endangered species. Despite poverty and political instabilities, the Forest and Soil Ministry and its line agencies, NGOs, civil society, international organizations like, IUCN, WWF, FAO, UNDP, The Japan International Cooperation Agency (JICA), UK-DFID, Care Nepal, and Winrock have been playing important roles to provide both technical and financial supports to enrich biodiversity conditions in Nepal. Though the landscape of Nepal represents only $0.1 \%$ of the global land surface, she offers world's top 20 global biodiversity hotspots (ICIMOD, 2007). Out of the total 867 terrestrial eco-regions of the world, six biomes and twelve terrestrial eco-regions are found in four major physiographic zones of Nepal. This way Nepal has 118 ecosystems and ranks twenty-fifth in biodiversity (ICIMOD, 2007: xiv). About 75 vegetation types are found in Nepal (FAO, 1999: 20). Other important climatic factors influencing biodiversity and the composition of flora and fauna in Nepal include rainfall, winter snowfall, temperature, and aspects (Government of Nepal, 2002: 6).

The Kanchenjunga Complex includes the Kanchenjunga Conservation Area (KCA) in Nepal and its counterparts Khangchendzonga National Park in Sikkim and Qomolangma Nature Preserve (QNP) in Tibet (Basnet, 2008). This is a good example of transboundary biodiversity zone making trinational park between Nepal, India, and China (UNDP, 1998; Rastogi et al., 1997). The Sagarmatha-Makalu-Barun-Qomolangma Complex includes Sagarmatha National Park (SNP), Makalu Barun National Park (MBNP), and Langtang National Park (LNP) of Nepal, and QNP in Tibet. The Annapurna-Manaslu Complex, which includes Annapurna Conservation Area (ACA) and Manaslu Conservation Area (MCA) of Nepal, is a potential site for transboundary collaboration with Tibet (Figure 2c). The Shey-Phoksumdo-Dhorpatan Complex, which includes Shey Phoksumdo National Park (SPNP) and Dhorpatan Hunting Reserve (DHR) of Nepal, offers another opportunity for transboundary collaboration possibly pairing with the Mapang-Xong Li Complex of Tibet (Basnet, 2008). The Shuklaphanta Complex includes Royal Shuklaphanta Wildlife Reserve (RSWR) in Nepal continuing geographic extent to Dudwa National Park and Corbett National Park in India. These protected areas are linked through forest corridors. The Bardia Complex includes the Royal Bardia National Park (RBNP) and Bardia Extension Area (RBNP-EA) in Nepal, and Katerniaghat Tiger Reserve in India (Basnet, 2008). The Chitwan-Parsa-Valmiki Complex includes Royal Chitwan National Park (RCNP) and Parsa Wildlife Reserve (PWR) in Nepal, and Valmiki National Park and Wildlife Reserve (VWR) in India. To- 
gether with two wildlife sanctuaries called Sohagbarwa and Udaipur, both offer habitats for tigers, rhinoceros, and elephants. The Koshi Tappu Wildlife Reserve (KTWR, declared Ramsar site, since 1971) of Nepal also has potential to extend to India. These wetlands are of international significance because they provide habitat for a large number of migratory birds. Another potential site for such cooperation lies in the southeast corner of Nepal where the Singhalila protected area of West Bengal, India lies across the border (Basnet, 2008).

Similarly, Pakistan consists of three of the world's eight biogeography "realms" - Indo-Malayan, Pale arctic, and Afro-tropical, four of the world's ten "biomes" (desert, temperate grassland, tropical seasonal forest, and mountain), and three of the world's four "domains" - mountain, humid-temperate, and dry (Government of Pakistan, 2009). The presence of great variety of landscapes, including rangeland, forest, wetland, and other wildlife habitats make this country rich in biodiversity. Due to increasing political instabilities coupled with low rainfall, Pakistan holds the least varieties of biodiversity among the four countries in question (ADB, 2008: 13-14).

Above accounts reveal that though these countries have many rich biodiversity areas, some of them have been identified as hotspots because many of the biodiversity areas if not brought under special attention, could face several insurmountable problems beyond replenishment (FAO, 2003; UNEP, 2001: 105).

\section{Biodiversity hotspots}

Hotspots refer to rich biodiversity areas which are under the constant threats with the risk of losing important gene pools, if not protected immediately. This concept was first proposed by Myers (1988 \& 1990), and later was revised and republished by Mittermeier et al. (2000). There are several biodiversity hotspots in the study areas. These hotspots are home for important populations of numerous large birds and mammals, including vultures, tigers, elephants, rhinos and wild water buffalo. In order to be classified under these hotspots, a biodiversity rich area must meet two strict criteria: a) the presence of at least 1,500 species of vascular plants (>0.5\% of the world's total) as endemics, and $b$ ) must have lost at least $70 \%$ of its original habitat (Conservation International -CI 2010). Aral Sea covering the coastal areas of India and Pakistan (Figure 1) meets the criteria of the World's 34 recognized biodiversity hotspots (CI 2010). It covers 2.3\% of the Earth's surface, and has lost $70 \%$ of its original vegetation coverage. Despite these threats, it still houses $50 \%$ of the world's plant species (Sea 2010).

One of the largest biodiversity hotspots - the Himalaya, stretches in an arc over 3,000 kilometers of northern Pakistan, Nepal, Bhutan and the northwestern and northeastern states of India. It includes all of the world's mountain peaks higher than 8,000 meters. The mountains rise abruptly offering diverse ecosystems ranging from alluvial grasslands and subtropical broadleaf forests to alpine meadows above the tree line. Vascular plants have even been recorded at more than 6,000 meters elevation. This includes the world's highest mountain, Sagarmatha (Mt. Everest) as well as several of the world's deepest river gorges. The major hotspots of this region include Nanda Devi (Kumaon-Garhwal Himalayas, India), Northern Sikkim and Eastern Nepal (India, Nepal), Namdapha (India), and Kashmir Himalayas (India and Pakistan) (IUCN, 2003; UNEP, 2000; Bhandari, 2012).

Though outside from the study area, another hotspot area of two of Asia's major mountain ranges, the Mountains of Central Asia were known to early Persians as the "roof of the world," also has influence on the biodiversity of the Himalayan range. In this region, the hotspot's ecosystems range from glaciers to desert, and include a highly threatened type of walnut-fruit forest, unique to this region, which contains ancestors of domestic fruit varieties and is an important storehouse of genetic diversity. The hotspot is also home to a rich variety of ungulates, including the threatened argali wild sheep.

Another hotspot area is the Western Ghats of southwestern India, locally known as the Sahyadri Hills. These hills are formed by the Malabar Plains and the chain of mountains running parallel to India's western coast, about 30 to 50 kilometers inland. They cover an area of about $160,000 \mathrm{~km}^{2}$ and stretch for 1,600 kilometers from south to north (Gujarat) (Figure 2b), interrupted only by the 30 kilometers Palghat Gap (Conservation International, 2010). Within the geographic ranges of these Ghats are Agastyamalai Hills, Nilgiri Hills, Nallamalai Hills, and Andaman and Nicobar Islands (IUCN, 2003; UNEP, 2000). These Ghats face tremendous population pressure where forests have been dramatically impacted to meet the demands for timber and agricultural land. Remaining forests are heavily fragmented where increased ecological stresses created due to farming, logging, and poaching has irreversibly impacted on the biodiversity. These hotspots are home for 
rare plants, reptiles, and amphibians. Among them include Asian elephants, Indian tigers, and the endangered lion-tailed macaque, and over 140 native species of fishes. The forests of the Western Ghats are also logged selectively. As a result, they are highly fragmented throughout their entire ranges. Many of the natural forests have been converted to monoculture plantations of tea, coffee, rubber, oil palm, teak, eucalyptus, and wattle, and are also cleared for building reservoirs, roads, and railways. Grazing by cattle and goats within and near protected areas has caused severe erosion on previously forested slopes. As of 2010 records, only $20 \%$ of the original forest remains in more or less pristine state in this region. These pristine forests are found in blocks larger than $200 \mathrm{~km}^{2}$ in the Agasthyamala Hills, Cardamom Hills, Silent Valley-New Amarambalam Forests, and southern parts of the South Kannada District in Karnataka State. Uncontrolled tourism and forest fires are additional concerns to biodiversity. Human-wildlife conflicts are in the rise each day. As a result, losses of crops and even human lives due to raiding of elephants and leopards killing livestock have added many woes to people living nearby these hotspots areas. To make the situation worse, government compensation for farmers are generally not prompt and adequate. These problems often lead to politically motivated agitations often led by radical and human rights groups.

Other hotspot areas of the regions are Sunderbans located along the coastal range of Bangladesh and India (UNEP, 2001: 113). These Sunderbans cover about one million hectares in the tri-delta areas of the rivers Ganga, Brahmaputra and Meghna. Bangladesh constitutes about $60 \%$ of the area, and India constitutes about $40 \%$ of the area. Sunderbans in Bangladesh are divided into Sunderbans West (71,502 ha), Sunderbans East (31,226 ha), and Sunderbans South (36,970 ha). About 23.5\% of the Sunderbans areas in Bangladesh are under the protected sanctuaries and rest of the areas area managed under the Integrated Protected Area Management (ADB, 2010). Similarly, in the Indian side, the Sunderbans are managed under the national park system (Selvam, 2003: 758). These areas are influenced by the tropical monsoonal climate with an annual rainfall of 1,600-1,800 mm, and encounter severe cyclonic storms (Gopal and Chauhan, 2006: 338). These cyclonic storms often disturb ecosystem services. The geographic ranges of transboundary hotspots are presented in Table 5.

Table 5. The Major Hotspots of Bangladesh, India, Nepal, and Pakistan

\begin{tabular}{|l|l|l|l|}
\hline The Western Ghats & & The Himalaya & \\
\hline Hotspot Original Extent $\left(\mathrm{km}^{2}\right)$ & 189,611 & Hotspot Original Extent $\left(\mathrm{km}^{2}\right)$ & 741,706 \\
Hotspot Vegetation Remaining $\left(\mathrm{km}^{2}\right)$ & 43,611 & Hotspot Vegetation Remaining $\left(\mathrm{km}^{2}\right)$ & 185,427 \\
Endemic Plant Species & 3,049 & Endemic Plant Species & 3,160 \\
Endemic Threatened Birds & 10 & Endemic Threatened Birds & 8 \\
Endemic Threatened Mammals & 14 & Endemic Threatened Mammals & 4 \\
Endemic Threatened Amphibians & 87 & Endemic Threatened Amphibians & 4 \\
Extinct Species $\dagger$ & 20 & Extinct Species $\dagger$ & 0 \\
Human Population Density (people/ $\left./ \mathrm{km}^{2}\right)$ & 261 & Human Population Density $\left(\right.$ people $\left./ \mathrm{km}^{2}\right)$ & 123 \\
Area Protected $\left(\mathrm{km}^{2}\right)$ & 26,130 & Area Protected $\left(\mathrm{km}^{2}\right)$ & 112,578 \\
Area Protected $\left(\mathrm{km}^{2}\right)$ in Categories I-IV* & 21,259 & Area Protected $\left(\mathrm{km}^{2}\right)$ in Categories I-IV* & 77,739 \\
\hline
\end{tabular}

Notes: $\uparrow$ Recorded extinctions since 1500 . * Categories I-IV affords higher levels of protection.

Source: Conservation International (2010).

The above account reveals that despite being rich in biodiversity, South Asia is facing several problems to conserve biodiversity (ADB, 2004; FAO, 1999; WRI, 2010). The Global Biodiversity Strategy (WRI/IUCN/UNEP, 1992) and the United Nations Economic and Social Commission for Asia and the Pacific (ESCAP) - ADB (2000) broadly identify six fundamental causes of biodiversity losses in South Asia. These include (1) unsustainably high rates of natural resource consumption by the growing human population; (2) steadily narrowing spectrum of traded products from agriculture and forestry, (3) introduction of exotic species associated with agriculture, forestry and fisheries (including bio-engineered species); (4) economic systems and policies that fail to value the environment and its resources; (5) inequity in ownership and access to natural resources, including the benefits from use and conservation of biodiversity, and inadequate knowledge and inefficient use of information; and (6) weak legal and institutional systems that fail to protect against unsustainable exploitation of resources (ESCAP-ADB, 2000). A research conducted by Tribhuvan University (2007) generalizes that the major causes of biodiversity losses due to the lack survival alternatives and increasing poverty in the region. 


\section{Biodiversity conservation problems}

Though biodiversity is essential to provide ecosystem services for the human well beings, it is very difficult to develop a specific conceptual framework that is applicable to all the countries (Escobar, 1998) to address all the issues identified by the ESCAP and ADB (2000). Nonetheless, Poiani et al. (2000) argued for a generalized framework based on the focal ecosystems, species composition, and supporting natural processes within their natural spatial extents as one stepping stones to develop biodiversity conservation strategies. Despite housing spectacular natural beauty and biological wealth, and harboring diverse ecosystems, continuous destruction of habitats due to increasing deforestation, loss of wetlands, rapid population growth, and agriculture expansion onto forest, unprecedented changes in biodiversity composition are likely to occur in this region (UNEP-DA, 2008: xiii). A threat to the biodiversity due to fragmenting several habitats followed by influence of capitalist economy and globalization, industrial growth, and urban expansion are adding incurable woes to conserve biodiversity. In many instances, the excess of industrial affluent onto fresh water has polluted water bodies affecting the habitats of aquatic flora and fauna. In term of the urban growth, in the 1950, only $15.6 \%$ population lived in urban area in the South Asian region, but as of 2010, this has increased to over 30.1\% (ESCAP, 2010). Looking at the cases of individual country for 1980-2000, it reveals that urban population in Bangladesh grew by 3.5\% (as opposed to rural $0.62 \%$ ); India $2.3 \%$ (rural 0.44\%); Nepal 4.8\% (rural $1.39 \%$ ) and Pakistan 3.3 (rural $1.30 \%$ ) between 1980 and 2000 (UNPF, 2010). These expansions have been possible only at the expense of forest coverage. A change in the forest coverage means a change in the evapotransiptation rates and microclimate (Cleugh, 1998). There have been expansions of agricultural land onto forest. Though even after the independence since 1971, Bangladesh did not see many changes in its forest cover (15.18\% in 1971, $13.6 \%$ in 2001, and $17.49 \%$ in 2010) (Khan et al., 2007) mainly due to the location of forest areas in low elevation level to expand urban and farmland onto forest, India saw $2.3 \%$ annual deforestation mainly due to the conversion of forest into farmland and settlements. Though social forestry drive has brought several areas under plantation, deforestation has been a regular process to support subsistence economy in India (Poffenberger, 2000; Ministry of Environment \& Forests Government of India, 2009). In Pakistan, only $2.78 \%$ of the land surface is under forest cover, and thus, there is not much expansion onto forest area for farming and urban expansion (WRI, 2010). In addition to urban and farmland expansions onto forest, large-scale mono cultivation has affected biodiversity in almost all the countries of study area (FAO, 2003). For example, in Bangladesh $46.85 \%$ of total forest cover has been planted with commercial species, 50.18\% in India, 3.41\% in Nepal, and 41.51\% in Pakistan (FAO, 2003; Perera and Fernando, 2004). This commercial mono-cropping do not contribute to biodiversity (McNeely and Scherr, 2003; Meilleur and Hodgkin, 2004).

Natural disasters also have threatened biodiversity. For example, in Bangladesh between 30-50\% of land surface encounters flood each year (FAO, 1988; UNISDR and World Bank, 2009). In India, floods affect an average of 8 million hectares annually, out of which 3.7 million hectares are cropped lands. Likewise, in Nepal, many of the Tarai districts get inundated due to overflow from the river beds and from dams constructed between Indo-Nepal border, and about 12,000 landslides occur in Nepal each year (UNISDR, 1999). Pakistan is no exception to these disasters, where flood annually damages approximately $3.5 \%$ of the crop land (UNISDR and World Bank, 2009). Floods have direct impacts on the biodiversity due to the damages of crops, destruction of aquatic floral and faunal lives, and also due to the development of salts on the fertile lands as the water evaporates. All four countries face many interrelated problems to conserve biodiversity due to their subsistence economies and the lack of interregional cooperation.

The intertwined relationships revolve around the economic development, resource uses, and biodiversity conservation and losses. Similar to the remarks made by the European Commission, the change in human activities such as population, economic and institutional settings as well as the changes in the land use patterns through the unsustainable use of resources have direct impacts on biodiversity (2009: 14 and 28). The WWF (1997: 17) concludes that biodiversity suffers at the hands of many individuals' decisions about resource use as these decisions are rational within the given set of socioeconomic parameters. For example, social structures, prices and market opportunities, cultural expectations, institutions, and laws all influence biodiversity conservation. Similar to what Poiani et al. (2000) argued to devise focal ecosystem framework, probably, the countries in question could devise policies, institutions, structures, and norms that promote biodiversity conservation by providing benefits to people whose primary dependence is on nature. This step might help in biodiversity conservation and even to arrest unprecedented climate changes through carbon 
sequestration. It is true that any types of development can lead to the growth of consumption. Some political and economic structures and policies favor resource transformation as neoclassical economists argue; however, there is no universal mechanism to value biodiversity and sustainable management systems (WWF, 1997). Probably, a market based policy instrument might help to alleviate these interrelated problems.

\section{Weak institutional approaches to biodiversity conservation}

Though several institutional approaches have been taken to conserve biodiversity at various scales, still institutionalization of biodiversity conservation across the region has been missing. Some of the notable work at the global scale include the UN Convention on Biological Diversity (CBD), Convention on the Conservation of Migratory Species of Wild Animals (CMS), Convention on International Trade in Endangered Species of Wild Fauna and Flora (CITES), International Plant Protection Convention (IPPC), Convention on the Conservation of European Wildlife and Natural Habitats (the Bern convention), UN Framework Convention on Climate Change (UNFCCC) (binding political resolutions with biodiversity conservation), the 2002 UN Johannesburg Plan of Implementation on sustainable development, Action plans, Codes of conduct and best practice with biodiversity relevance by authoritative organizations such as FAO UNEP, IUCN, International Council for the Exploration of the Sea (ICES), and UN Millennium Development Goals (MDGs). These four Asian countries have followed the global footsteps to institutionalize biodiversity conservation. All four countries have taken initiative in in-situ conservation. Ex-situ conservation includes policy directives in the agriculture, forest, inland water and conservation of mountain biological diversity (Desai et al., 2011). Despite international call, Bangladesh, India, Nepal and Pakistan are not practically ready to adopt the call of $\mathrm{CBD}$, and they are not prepared to address the root cause of the biodiversity losses. Lack of clear policies and budget has been blamed for the failure to institutionalize biodiversity conservation (Carew-Reid, 2002; Desai et al., 2011; Living Planet Report, 2010). As a result, loss of biodiversity continues because current policies and economic systems do not incorporate the values of biodiversity effectively in the political or the market systems (UNEP, 2007: 159). WWF Living Planet Report (2010: 12) observes rapid habitat loss, fragmentation of habitats, over-exploitation of wild species, increasing pollution, climate change and increase in invasive species in all these countries. The major stakeholders of biodiversity (73\% population in Bangladesh; $71 \%$ in India, 83\% Nepal and 64\% in Pakistan) living on subsistence farming do not receive any incentives to conserve biodiversity. Other people who live in low income of less than $\$ 1$-a-day (17\% of the total population in Bangladesh, 33.5\% in India, 24\% in Nepal, and 33.5\% Pakistan) are the major stake holders of biodiversity, but suffer in the pretext of biodiversity conservation (MEA, 2005; ADB-ICIMOD, 2006; UNEP, 2007; CBD, 2011). Until or unless these countries are able to overcome the problems of population growth, poverty, hunger, disease, homelessness, gender inequality, it will be difficult to improve biodiversity conservation. Our personal experiences from these countries reveal that unless there are strong institutional set up to provide living alternatives to low income people, it will be difficult to materialize the biodiversity conservation objectives (United Nations, 2011).

As of today, these countries have not fully and seriously applied the global call in addressing the biodiversity issues with an institutional arrangement that will address the biodiversity conservation across the countries like the European Union does. Since the biodiversity conservation issues are related to the management of forest, water resources, wetland / coastal areas, an institution that can have administrative jurisdiction across the countries is missing in this region. Though each country its own institutional set-up, differences in their operating systems, it has been difficult to coordinate among the umbrella organizations. The CBD can be considered as the global institution whose mandate would help achieve the set goal of conservation (CBD, 2011). The signatory countries are supposed to submit the progress report every year. So far fourth report has been submitted from the countries of this study. These reports largely reports overview of biodiversity: status, trends and threats; the current status of the national biodiversity strategy and action plan; sectoral and cross-sectoral integration or mainstreaming of biodiversity considerations (Government of Bangladesh, 2010; Government of India, 2009; Government of Nepal, 2009; Government of Pakistan, 2009); but do not present coordinated efforts made to conserve biodiversity. There is no doubt, each country wants to achieve the CBD's set goals, however, these regional cooperative agendas have been turned into bilateral ones due to political rivalries among these countries, for example, India vs. Pakistan. These countries in question have been participating in international organizations, for example, the Stockholm Conference in 1972, and the Earth Summit in 1992, however the national policy guidelines related to biodiversity conservation and management are insufficiently articulated at the implementation level. For example, except for Pakistan, other three countries have not yet prepared the conservation strategies for the local level. 
Since the biodiversity conservation effort requires transboundary approaches, it needs a holistic policy directives and institutional setting, which can coordinate with the all national to local level stakeholders. These stakeholders include the environmental cell in the parliament which is responsible to prepare the policy directives, rules and regulations, the national planning commissions (NPCs), national development councils, national water resources development councils, environment protection councils, national commissions on sustainable development, and biodiversity coordination committees. Conservation of biodiversity is not possible, without proper public participation. In principles, there are several international and non-governmental actors involved for conservation of the biodiversity associated with the human wellbeing (FAO, 1997; Government of Pakistan, 2000; Indian National Science Academy, 2001; Government of Nepal, 2004; Biswas and Islam, 2004; Government of India, 2007; ICIMOD, 2007) however, there is no clear policy directives or modalities and roles identified for these external actors activities at the program implementation level.

Good governance is needed for the conservation of biodiversity. Table 6 provides an overall governance performance in terms of six commonly functional parameters (Kaufmann, Kraay and Mastruzzi, 2010). If these six parameters are considered as performance indicators in biodiversity conservation as proposed by Kaufmann et al. (2010) in the Likert Scale of 1-100, India holds the best position, followed by Bangladesh on Voice and Accountability, Political Stability and Absence of Violence, and Rule of Law ( ${ }^{\text {nd }}$ among the four); Pakistan in Government Effectiveness and Regulatory Quality ( $2^{\text {nd }}$ among four); and Nepal, which is $2^{\text {nd }}$ among the four in Control of Corruption. In Political Stability and Absence of Violence Pakistan scores the worst in the World and Nepal $8^{\text {th }}$ worst.

Table 6. Governance Performance (World Bank Report of 2010 by Kaufmann et al., 2010)

\begin{tabular}{|l|c|c|c|c|c|c|c|c|c|c|c|c|}
\hline & \multicolumn{2}{|c|}{ VA } & \multicolumn{2}{c|}{ PA } & \multicolumn{2}{c|}{ GE } & \multicolumn{2}{c|}{ RQ } & \multicolumn{2}{c|}{ RL } & \multicolumn{2}{c|}{ CC } \\
\hline & $\begin{array}{c}2008 \\
\text { Rank }\end{array}$ & $\begin{array}{c}\text { Score } \\
\text { est. }\end{array}$ & $\begin{array}{c}2008 \\
\text { Rank }\end{array}$ & $\begin{array}{c}\text { Score } \\
\text { est. }\end{array}$ & $\begin{array}{c}2008 \\
\text { Rank }\end{array}$ & $\begin{array}{c}\text { Score } \\
\text { est. }\end{array}$ & $\begin{array}{c}2008 \\
\text { Rank }\end{array}$ & $\begin{array}{c}\text { Score } \\
\text { est. }\end{array}$ & $\begin{array}{c}2008 \\
\text { Rank }\end{array}$ & $\begin{array}{c}\text { Score } \\
\text { est. }\end{array}$ & $\begin{array}{c}2008 \\
\text { Rank }\end{array}$ & $\begin{array}{c}\text { Score } \\
\text { est. }\end{array}$ \\
\hline India & 59 & 0.45 & 17 & -0.99 & 54 & -0.03 & 47 & -0.21 & 56 & 0.12 & 44 & -0.37 \\
\hline Bangladesh & 31 & -0.61 & 10 & -1.54 & 26 & -0.73 & 35 & -0.47 & 27 & -0.7 & 29 & -0.68 \\
\hline Nepal & 25 & -0.79 & 8 & -1.69 & 24 & -0.75 & 27 & -0.66 & 25 & -0.76 & 25 & -0.77 \\
\hline Pakistan & 19 & -1.01 & 1 & -2.5 & 23 & -0.77 & 21 & -0.82 & 19 & -0.92 & 11 & -1.1 \\
\hline
\end{tabular}

Notes: VA = Voice and Accountability (rank and estimation); PA = Political Stability and Absence of Violence; GE $=$ Government Effectiveness; RQ = Regulatory Quality; RL = Rule of Law; CC = Control of Corruption; Est. = score estimate of 2008; Rank = 0-100;

WGI measures the standard normal units of the governance indicator, ranging from around -2.5 (low performance) to 2.5 (high performance), and in percentile rank terms ranging from 0 (lowest) to 100 (highest) among all countries worldwide. The column labeled "Est." provides the point estimate. (Disclaimer: The governance indicators presented here reflect the statistical compilation of responses on the quality of governance given by a large number of enterprise, citizen and expert survey respondents in industrial and developing countries, as reported by a number of survey institutes, think tanks, non-governmental organizations, and international organizations as in Governance Matters VIII: Governance Indicators for 1996-2008).

Out of six indicators, India is only above the average in VA; GE and RL; however, it scores minus 0.99 with $17^{\text {th }}$ rank (out of 0-100) and it not been able to appropriately address the issue of corruption (ran only 44 and score -0.37). The status of other three counties is significantly low as compared to India and in the global context. For example, Pakistan is worse performing country with the $1^{\text {st }}$ rank and lowest score -2.5 and Nepal $8^{\text {th }}$ with the score of -1.69 , Bangladesh $10^{\text {th }}$ with the score of -1.54 in Political Stability and Absence of Violence. Similarly, corruptions seem a major problem in all four countries, whereas Pakistan ranks $11^{\text {th }}$ with the score of -1.1 among the most corrupted country in the world. These scenarios indicate that countries of this study have not fully institutionalized the basic of governance (VA; PA; GE; RQ; RL; and CC); therefore, it is difficult to expect the readiness for institutionalization of the biodiversity conservation.

\section{Conclusion}

The conservation of biodiversity is an enormously complicated and difficult task requiring information flow to different levels under a fully functional government. The conservation efforts need networking of individuals, organizations and information systems with the support of an appropriate information network (Geevan, 1995: 914). Biodiversity governance cannot be separated from the economic activities, political stabilities, and effective administrative setup. Since these aspects are found in fragile conditions in the countries in question, it is difficult to achieve the expectations set by the CBD for biodiversity conservation. 
This analysis have revealed that as long as there are no alternatives to support the living conditions of poor people who depend on primary economic activities, these communities would be reluctant to participate in the conservation of biodiversity. There is an urgent need for the equitable governance for biodiversity conservation from the local to national level that engages all concerned stakeholders. This need is urgently needed for Bangladesh, Nepal, and Pakistan. These countries need to strengthen their institutional infrastructure to obtain the goals of the CBD through specific programs to provide living alternatives to low income peoples. Environmental monitoring and coordinated reporting systems have to be institutionalized in these countries. Without strengthening institutional aspects, it will be difficult to promote collaborations at international levels, maintain transparency, and launch public awareness programs to conserve biodiversity and its importance to human wellbeing. It is essential that the governments at each level need to develop implementation mechanisms that are currently inefficient in enabling the local stakeholders to reduce the negative impact on biodiversity. Corrective measures are needed to involve all concerned stakeholders and government in the biodiversity conservation bandwagon.

It is important that the institution must bear the holistic approach and set the clear responsibilities of all stakeholders and more cooperative efforts towards ensuring the biodiversity conservation and show improvement in the performance indicators. Developing a strong institutional architecture for biodiversity conservation would help to achieve the common goals through the sharing of highly reliable and meaningful information system at different levels. These countries are still under the top-down approaches of governances. Pro-people centric bottom up approaches could be helpful to conserve biodiversity, however, it is still matter of investigation on what would be the most appropriate model to enhance the equity which ultimately helps local poor for the sustainable livelihood that would motivate them to conserve biodiversity.

\section{Acknowledgement}

I would like to thank to Prof. Keshav Bhattarai and Ms. Prajita Bhandari for their insightful thoughts and comments on the paper, without their support this research was impossible. I would also thanks to Manaslu; Prameya and the reviewer panel for their input and comments.

\section{References}

1. ADB (2004). Country Strategy and Program 2005-2009: Nepal, Asian Development Bank, Manila Philippines. Retrieved from http://www.adb.org/Documents/CSPs/NEP/2004/csp0100.asp (accessed on 09/09/2010).

2. ADB (2006). Environment Assessment of Nepal: Emerging Issues and Challenges, ADB, Manila, ICIMOD, Kathmandu. Retrieved from http://www.adb.org/Documents/Books/emerging-issues-challenge/.

3. ADB (2008). Islamic Republic of Pakistan Country Environment Analysis, Asian Development Bank, Manila. Retrieved from http://www.adb.org/documents/assessments/country-environmental/pak/countryenvironment-analysis.pdf.

4. Alkire, Sabina and Santos, Maria Emma (2010). Multidimensional Poverty Index: 2010 Data. Oxford Poverty and Human Development Initiative.

5. Balian, E., Harrison, I., Butchart, S. H. M., Chambers, P., Cordeiro, J., Cumberlidge, N., de Moor, F., Gascon, C., James, H., Kalkman, V., van Dijk, P. P. and Yeo, D. (2010). A Wealth of Life: Species Diversity in Freshwater Systems, pp. 50-89. in Mittermeier, R. A., Farrell, T. A., Harrison, I. J., Upgren, A. J. and Brooks, T. M. Freshwater - the essence of life. Washington, DC: Conservation International and CEMEX.

6. Barbier, Edward B., Burgess, Joanne C., and Folke, Carl (1994). Paradise Lost? The Ecological Economics of Biodiversity. London: Earthscan Publications.

7. Basnet, K. (2008). Transboundary Biodiversity Conservation Initiative. Journal of Sustainable Forestry. Available online: http://www.tandfonline.com/loi/wjsf, September 2008.

8. Bhandari, Medani P. (2012). Environmental Performance and Vulnerability to Climate Change: A Case Study of India, Nepal, Bangladesh, and Pakistan. Climate Change and Disaster Risk Management. Series: Climate Change Management, 149-167. Springer, New York / Heidelberg, ISBN 978-3-642-31109-3.

9. Bhandari, Medani P. (2012). Exploring the International Union for the Conservation of Nature (IUCN's) National Program Development in Biodiversity Conservation: A Comparative Study of India, Pakistan, Nepal, and Bangladesh. Sociology - Dissertations, 73. Retrieved from http://surface.syr.edu/soc_etd/73.

10. Carew-Reid, Jeremy (2002). Biodiversity Planning in Asia. IUCN, Gland, Switzerland and Cambridge, UK 594 + vi pp. ISBN 2-8317-0643-2. 
11. CIA (2010). The World Fact Book. Government of the United States of America, The Central Intelligence Agency, Office of Public Affairs, Washington, D.C.

12. Cleugh, H. A. (1998). Effects of windbreaks on airflow, microclimates and crop yields. Agroforestry Systems, 41, 55-84.

13. Conservation International (2010). The biodiversity hotspots, The Himalaya Hotspot, Conservation International. Arlington, VA. Retrieved from http://www.conservation.org/where/priority_areas/ hotspots/asia-pacific/Himalaya/Pages/default.aspx.

14. Corcoran, E., Nellemann, C., Baker, E., Bos, R., Osborn, D., Savelli, H. (eds). (2010). Sick Water? The central role of wastewater management in sustainable development. A Rapid Response Assessment. United Nations Environment Programme, UN-HABITAT, GRID-Arendal. www.grida.no.

15. Desai, B.H., Oli, K.P, Yang, Yongping, Chettri, N., Sharma, E. (2011). Implementation of the Convention on Biological Diversity: A retrospective analysis in the Hindu Kush-Himalayan countries. Kathmandu: ICIMOD. Retrieved from http://books.icimod.org/uploads/tmp/icimodimplementation_of_the_convention on_biological diversity.pdf.

16. Earbirding.com (2010). Recording, identifying, and interpreting bird sounds. Demand Media, Santa Monica, CA, USA. Retrieved from http://earbirding.com/blog/archives/date/2010/05.

17. Ehrenfield, D. (1978). The Arrogance of Humanism. Oxford University Press, Oxford.

18. EPI (2010). Environmental Performance Index, Summary for Policymakers. Yale Center for Environmental Law and Policy, CT and Columbia University in collaboration with the World Economic Forum, Geneva, Switzerland, Joint Research Centre of the, European Commission, Ispra, Italy. Retrieved from http://epi.yale.edu/epi-2010.pdf.

19. ESCAP (2010). Statistical Yearbook for Asia and the Pacific 2009. The United Nations Economic and Social Commission for Asia and the Pacific (ESCAP). The United Nations Building, Rajadamnern Nok Avenue, Bangkok, Thailand. Retrieved from http://www.unescap.org/stat/data/syb2009/ESCAPSYB2009.pdf.

20. ESCAP and ADB (2001). Asian Environment Outlook 2001. Asian Development Bank, Manila. Retrieved from http://www.rrcap.unep.org/pub/soe/sa_part2_5.pdf. Retrieved on June 27, 2011.

21. Escobar, Arturo (1998). Whose Knowledge, Whose nature? Biodiversity, Conservation, and the Political Ecology of Social Movements. Journal of Political Ecology, 5.

22. European Union-EU (2009). Study on understanding the causes of biodiversity loss and the policy assessment framework, in the context of the Framework Contract (No DG ENV/G.1/FRA/ 2006/0073, Specific Contract No-DG.ENV.G.1/FRA/2006/0073) (prepared by Allister Slingenberg, Leon Braat, Henny van der Windt, Koen Rademaekers, Lisa Eichler, Kerry Turner) for European Commission, Directorate-General for Environment, Brussels. Retrieved from http://ec.europa.eu/environment/enveco/biodiversity/pdf/causes_biodiv_loss.pdf.

23. FAO (1988). Agro-ecological Regions of Bangladesh. FAO, Rome.

24. FAO (1999). Forest Resources of Nepal Country Report (FRA 2000). Forest Resources Assessment Program Working Paper 16, Forestry Department, Food and Agriculture Organization of the United Nations, Rome.

25. FAO (2003). Asia-Pacific Forestry Commission: State of Forestry in Asia and the Pacific - 2003: Status, changes and trends. Rap Publication 2003/22.

26. FAO (2003). Guidelines for Establishing Audits of Agricultural-Environmental (AG-EN) Hotspots. Food and Agriculture Organization of The United Nations, Rome.

27. FAO (2009). Coping with a changing climate: considerations for adaptation and mitigation in agriculture. Food and Agriculture Organization of the United Nations Rome.

28. FAO (2011). State of the World's Forests. Food and Agriculture Organization of the United Nations, Rome. Retrieved from http://www.fao.org/docrep/013/i2000e/i2000e.pdf.

29. Fargione, J., Hill, J., Tilman, D., Polasky, S. and Hawthorne, P. (2008). Land clearing and the biofuel carbon debt. Science 319: 1235-1238.

30. Geevan, C.P. (1995). Biodiversity Conservation Information Network: A Concept Plan. Current Science, 69, 906-914.

31. Gopal, B. and Chauhan, M. (2006). Biodiversity and its Conservation in the Sundarban Mangrove Ecosystem. Aquatic Sciences, 68, 338-354.

32. Government of Bangladesh (2010). Fourth National Report to the Convention on Biological Diversity (Biodiversity National Assessment and Program of Action 2020). Ministry of Environment and Forests, Government of the People's Republic of Bangladesh, Dhaka. 
33. Government of India (2009). India's Fourth National Report to the Convention on Biological Diversity. Ministry of Environment and Forests Government of India, New Delhi.

34. Government of India (2010). Conserving Biodiversity of the Country (input from: Dr G.V. Sarat Babu and Dr Sujata Arora). Military News, Ministry of Defense, New Delhi. Retrieved from http://mod.nic.in/samachar/1may/html/para.htm.

35. Government of Nepal (2002). The Position paper for the National Development Forum Meeting (February 4-8, 2002, Ministry of Finance, April 2002, p. 23) Ministry of Finance, Government of Nepal, Kathmandu.

36. Government of Nepal (2009). Nepal Fourth National Report to the Convention on Biological Diversity. Government of Nepal, Ministry of Forests and Soil Conservation Singha Durbar, Kathmandu, Nepal.

37. Government of Pakistan (2009). Fourth National Report, Convention on Biological Diversity. Government of Pakistan Ministry of Environment, Islamabad.

38. Government of Pakistan (2009). Implementation of the UU Framework Convention on Climate Change (UNFCCC) in Pakistan (presented by Ahmad Jan Malik Section Officer (NCS-1). Ministry of Environment, Islamabad. Retrieved from http://www.ap-net.org/docs/14th_seminar/malik.pdf (accessed on 06/03/2010).

39. Henley, Michelle and Henley, Steve (2007). Biodiversity - what does it mean? Transboundary Elephant Research Programme, Wilderness Trust, UK. Retrieved from http://www.savetheelephants.org/files/South\%20Africa/Reports/Other/Biodiversity.pdf.

40. ICIMOD (2007). Nepal Biodiversity Resource Book (Protected Areas, Ramsar Sites, and World Heritage Sites). ICIMOD, MOEST, GoN, Kathmandu, Nepal.

41. IUCN (2003). IUCN in Asia: Growing Together - Ecosystems and Livelihoods. IUCN, Bangkok, Thailand and Gland, Switzerland.

42. IUCN (2007). Identification and Gap Analysis of Key Biodiversity Areas, Targets for Comprehensive Protected Area Systems, Best Practice Protected Area Guidelines Series No. 15. World Commission on Protected Areas, IUCN, Gland.

43. IUCN (2010). Regional Activities of Asia. IUCN, Bangkok. Retrieved from http://cms.iucn.org/about/union/secretariat/offices/asia/regional_activities/.

44. Khan, M. A. S. A., Uddin, M. B., Uddin, M. S., Chowdhury, M. S. H., and Mukul, S. A. (2007). Distribution and Status of Forests in the Tropics: Bangladesh Perspective, Pakistan Academy of Science, 44(2), 145-153.

45. Khera, N. and Kumar, A. (2010). Impact Assessment and Project Appraisal, 28(3), 189-200.

46. Kothari, Ashish (1995). Sacrificing Our Future: The New Economic Policy and the Environment. Consumer Unity and Trust Society, Calcutta.

47. McNeely, J.A., and Scherr, S.J. (2003). Ecoagriculture: Strategies to Feed the World and Save Wild Biodiversity. Island Press, Washington D.C.

48. McNeely, Jeffery, et al. (1990). Conserving the World's Biological Diversity. Washington: IUCN.

49. Meilleur, B., and Hodgkin, T. (2004). In Situ Conservation of Crop Wild Relative: Status and Trends. Biodiversity and Conservation, 13, 663-684.

50. Meyer, William B. and Turner, B.L. II (1992). Human Population Growth and Global Land-Use/Cover Change. Annual Review of Ecology and Systematics, 23, 39-62.

51. Millennium Ecosystem Assessment (2005). Ecosystems and Human Well-being: Biodiversity Synthesis. World Resources Institute, Washington, DC. Retrieved from http://www.millenniumassessment.org/documents/document.354.aspx.pdf.

52. Ministry of Environment \& Forests Government of India (2009). State of Environment Report India, Environmental Information System (ENVIS). (C) Ministry of Environment and Forests, Government of India. Retrieved from http://moef.nic.in/downloads/home/home-SoE-Report-2009.pdf.

53. Mittermeier, R. A., Myers, N., and Mittermeier, C. G. (2000). Hotspots: Earth's Biologically Richest and Most Endangered Terrestrial Eco-regions. Conservation International, ISBN 978-9686397581.

54. Mittermeier, R.A., Robles-Gil, P., Hoffmann, M., Pilgrim, J.D., Brooks, T.B., Mittermeier, C.G., Lamoreux, J.L. and Fonseca, G.A.B. (2004). Hotspots Revisited: Earth's Biologically Richest and Most Endangered Ecoregions. CEMEX, Mexico City, Mexico.

55. Myers, N. (1988). Threatened biotas: hotspots in tropical forests. The Environmentalist, 8, 178-208.

56. Myers, N. (1990). The biodiversity challenge: Expanded hot spots analysis. The Environmentalist, 10, 243-256.

57. Nishanthi P. and Fernando, K. (2004). Sustainable Land Management: South Asia Perspectives, Subregional workshop on development of the South Asia Sub-regional Action Program, For combating des- 
ertification and Promoting sustainable land management 5-8th July 2004, Colombo, Sri Lanka, South Asia Cooperative Environment Program, Colombo, Sri Lanka.

58. Rap Publication (2003). State of forestry in Asia and the Pacific - 2003, Status, changes and trends Asia. Pacific Forestry Commission, Food and Agriculture Organization of The United Nations Regional Office for Asia and the Pacific, BangkokPacific - 2003: Status, changes and trends. Rap Publication. https://coin.fao.org/coin-static/cms/media/9/13171081010230/ad642e00.pdf.

59. Poffenberger, M. (Editor 2000). Communities and Forest Management in South Asia; A regional profile of the international Working Group on Community Involvement in Forest Management (WG-CIFM). Asia Forest Network USA and the International Union for Conservation of Nature (IUCN). Switzerland. Retrieved from http://www.asiaforestnetwork.org/pub/pub29.pdf (accessed on 04/23/2010).

60. Poiani, K., Aren, A., Brian, D., Richt, E.R., Anderson, Mark G., and Richter, Holly, E. (2000). Biodiversity Conservation at Multiple Scales: Functional Sites, Landscapes, and Networks. BioScience, 50(2), 133-146. Retrieved from http://science.natureconservancy.ca/salishsea/documents/Background/general/ Poiani\%20et\%20al\%202000.pdf.

61. Rastogi, A., Pei, S., and Amatya, D. (1997). Regional Consultation on Conservation of the Kanchenjunga Mountain Ecosystems. ICIMOD, Kathmandu.

62. Robinson, John B. (1991). Modeling the Interactions between Human and Natural Systems. International Social Science Journal, 43(4), 629-648.

63. SAARC (2010). Area of Cooperation-Environment. SAARC Secretariat, Kathmandu. Retrieved from http://www.saarc-sec.org/areaofcooperation/cat-detail.php?cat_id=54 (accessed on 06/30/2011).

64. Stern, Paul, Young, Oran and Druckman, Daniel, eds. (1992). Global Environmental Change: Understanding the Human Dimensions. Washington: National Academy Press.

65. The United Nations Economic and Social Commission for Asia and the Pacific (ESCAP) and ADB (2000). State of the Environment in Asia and the Pacific 2000. Economic and Social Commission For Asia, Asian Development Bank, Bangkok, Thailand.

66. Tribhuvan University (2007). Development of Financial Institutions in Nepal. Tribhuvan University, Kirtipur, Kathmandu, Nepal.

67. UNDP (2010). Global Human Development Report 2010. Human Development Report Office, New York. Retrieved from http://www.maplecroft.com/about/news/natural_disasters.html (Accessed on $5 / 26 / 2011)$.

68. UNEP (2001). South Asia: State of the Environment 2001. United Nations Environment Program, United Nations Environment Program, Regional Resource Centre for Asia and the Pacific (UNEP RRC.AP). Outreach Building, Asian Institute of Technology, Klong Luang, Pathumthani, Thailand. Retrieved from http://www.rrcap.unep.org/pub/soe/sa_cover.pdf.

69. UNEP (2002). Global Environment Outlook 3 (GEO 3) State Of The Environment And Policy Retrospective: 1972-2002. UNEP-United Nations Environment Program, Nairobi.

70. UNEP-GEMS (2007). Global Drinking Water Quality Index Development and Sensitivity Analysis Report. United Nations Environment Program Global Environment Monitoring System (GEMS)/Water Program, Ontario, Canada. Retrieved from http://www.gemswater.org/publications/pdfs/gwqi.pdf.

71. UNISDR (1999). Water Hazards, Resources and Management for Disaster Prevention: A Review of the Asian Conditions IDNDR 1991-1999. United Nations International Strategy for Disaster Reduction UNISDR, Palais des Nations, Geneva, Switzerland.

72. UNISDR and World Bank (2009). Global Facility for Disaster Reduction and Recovery. Disaster Risk Management Programs for Priority Countries, Global Facility for Disaster Reduction and Recovery GFDRR Secretariat, Washington, DC. Retrieved http://unisdr.org/files/14757_6thCGDRMProgramsforPriorityCountrie.pdf.

73. United Nations (2002). Country Profile of Government of India for World Summit for Sustainable Development (WSSD). United Nations, New York.

74. United Nations Economic Commission for Africa (2008). Sustainable Development Report on Africa, Five-Year Review of the Implementation of the World Summit on Sustainable Development Outcomes in Africa (WSSD+5). Economic Commission for Africa, Addis Ababa, Ethiopia. Retrieved from http://www.uneca.org/eca_resources/publications/books/sdra/index.htm.

75. United Nations Environment Program and Development Alternatives (2008). South Asia Environment Outlook 2009: UNEP, SAARC and DA. Retrieved from http://www.saarcsec.org/userfiles/SAEO\%202009.pdf.

76. United Nations Population Division (2001). World Population Prospects 1950-2050 (The 2000 Revision). New York, United Nations. 
77. United Nations Population Fund (2010). The State of World Population 2010, From conflict and crisis to renewal: generations of change. United Nations Population Fund, New York.

78. Vié, J.-C., Hilton-Taylor, C., Pollock, C., Ragle, J., Smart, J., Stuart, S.N. and Tong, R. (2008). The IUCN Red List: a key conservation tool. In: Vié, J.-C., Hilton-Taylor, C. and Stuart, S.N. (eds). The 2008 Review of the IUCN Red List of Threatened Species. IUCN Gland, Switzerland.

79. Vyas, V. S. and Reddy, V. Ratna (1998). Assessment of Environmental Policies and Policy Implementation in India. Economic and Political Weekly, 33(1/2), 48-54.

80. Wilson, Edward (1993). The Diversity of Life. New York: W.W. Norton.

81. World Bank (2010) World development report, Development and Climate Change. The International Bank for Reconstruction and Development / The World Bank, Washington DC.

82. World Bank Data (2011). Multi scale data portal. World Bank, Washington, DC. Retrieved from http://data.worldbank.org/data-catalog (accessed on 05/07/2011).

83. World Resource Institute (2010). Forests, Grasslands, and Dry lands - Pakistan; Earth Trend Country Profile. WRI, USA. $\quad$ Retrieved from http://earthtrends.wri.org/pdf_library/country_profiles/for_cou_586.pdf (accessed on 05/21/2010).

84. World Summit on Sustainable Development (WSSD) (2001). Task Force for the Preparation of WSSD in Asia and the Pacific. Asian Development Bank, United Nations Environment Program, United Nations Development Program, Economic and Social Commission for Asia and the Pacific (ESCAP). Bangkok, Thailand. Retrieved from http://www.rrcap.unep.org/wssd/documents/01_SA_Report.pdf.

85. WRI, IUCN and UNEP (1992). Global Biodiversity Strategy. World Resources Institute, Washington, DC.

86. WRI, UNEP, and IUCN (1995). National Biodiversity Planning: Guidelines Based on Early Experiences around the World. Washington: WRI.

87. WWF (1997). Socioeconomic Root Causes Of Biodiversity Loss: An Analytical Approach Paper for Case Studies (by Pamela Stedman-Edwards) For the Macroeconomics for Sustainable Development Program Office World Wide Fund for Nature December 1997, WWF-MPO Washington, D.C. Retrieved from http://assets.panda.org/downloads/analytic.pdf.

88. Cleugh, H.A. (1998). Effects of windbreaks on airflow, microclimates and crop yields. Agroforestry Systems, 41, 55-84. 